\title{
Jornadas de Junho de 2013: formas de mobilização online e a ação de ativistas em Brasília por meio do Facebook*
}

\section{June Jorneys of 2013: online mobilizations and the action of activists in Brasilia on Facebook}

Fernanda Fidelis ${ }^{1}$

Flor Marlene E. Lopes ${ }^{2}$
Recebido em: 05/05/2015. Aprovado em: 18/05/2015.

1 Possui graduação em Comunicação Social, pelo Centro Universitário de Brasília (2008), com a Monografia intitulada "Skinhead: Incursões no Movimento Estético"; Pós-Graduada Lato Sensu em Gestão Pública pelo Instituto Latino-Americano de Planejamento Educacional, ILAPE/JK, com artigo intitulado "Pré-sal: uma análise da assimetria de informação entre o governo Lula e a imprensa privada".

2 Doutora em Semiótica pela Universidade de São Paulo USP. Professora no Curso de Comunicação do Centro Universitário de Brasília e Coordenadora dos cursos de Pós-Graduação na Faculdade de Artes Dulcina de Moraes.

\section{Resumo}

Em junho de 2013, viram-se inúmeras manifestações populares que marcaram a memória do Brasil, à medida que o clamor social crescia e os atos ganhavam magnitude. Em relação à forma de articulação dessas manifestações, segundo pesquisa do IBOPE (2014), 77\% dos manifestantes tomaram conhecimento dos protestos por meio do Facebook, $1 \%$ utilizando Twitter, $8 \%$ os dois anteriores e $13 \%$ não se mobilizaram por meio das redes sociais virtuais. Este artigo averigua como os movimentos sociais em Brasília utilizaram o Facebook durante as Jornadas de Junho de 2013, bem como a abrangência do ativismo online como ferramenta de mobilização popular nesse período e de que maneira os ativistas independentes militaram por meio do Facebook. Para isso, estudamos as fanpages do Movimento Passe Livre e do Comitê Popular da Copa e os eventos criados no Facebook para convocar usuários dessa mídia social para as mobilizações off-line, para compreendermos, então, um pouco do caráter das mobilizações online nas manifestações de junho de 2013 referentes à Brasília.

Palavras-chave: Facebook. Jornadas de Junho 2013. Ativismo online. Movimento social.

\begin{abstract}
In July of 2013, we could see massive protests which from now on will remain part of the social memory of Brazil as the protests increased and got bigger proportions. It is important to highlight the forms of articulation that happened in these protests: according to IBOPE (2014), 77\% of the demonstrators found out about the protests through Facebook, 1\% using Twitter, 8\% using the two previous and $13 \%$ were not mobilized through social media. This study aims to investigate how the social movements used Facebook in Brasília during the protests on June of 2013; as well as, the inclusiveness of the online activism as a tool for popular mobilization and in which ways the independent activists made online activism on Facebook. We are going to study the fanpages of Movimento Passe Livre and Comitê Popular da Copa as well as the events created in Facebook to mobilize the users of this social network in order to motivate people to go to the streets during the protests. This way it will be possible to acknowledge the features of online mobilizations in the period of the June Journeys of 2013 in Brasília.
\end{abstract}

Keywords: Facebook. June Journeys of 2013. Online activism. Social movement. 


\section{Introdução}

No Brasil, as Jornadas de Junho surpreenderam a todos. E seu caráter enigmático, com motivações pouco claras, falta de lideranças e rápida expansão, apontaram para uma situação política de desconforto por parte da população. Dessa forma, o autor Lincoln Secco em Maricato et al. (2013, p. 71) afirma que: "nem a alta do dólar ou o aumento da inflação podiam ser o motivo decisivo das revoltas. Ao contrário, a perplexidade adveio da manifestação puramente política, ainda que detonada pelos aumentos de tarifas de transporte público". As tarifas, com efeito, diminuíram em dezenas de cidades do Brasil $₫$ no entanto, os protestos prosseguiram.

Este estudo teve como objetivo principal investigar como os movimentos sociais, em especial, o Movimento Passe Livre (MPL-DF), o Comitê Popular da Copa do Distrito Federal e ativistas independentes de Brasília utilizaram o Facebook nas Jornadas de Junho de 2013. A pesquisa foi exploratória sendo em parte teórica (por meio de pesquisa bibliográfica), eparte empírica (entrevistas, estudo das fanpages e eventos). Fizemos o estudo por meio de entrevistas e investigação de algumas postagens selecionadas das fanpages dos respectivos movimentos sociais e eventos criados por movimentos sociais e ativistas independentes. Para tanto, tentamos responder às seguintes perguntas: como se deu a organização dos eventos dos atos de junho de $2013 \mathrm{em}$ Brasília no Facebook? Qual foi o acesso ${ }^{3}$ a que tiveram esses eventos? Como foi a atuação dos movimentos sociais (MPL-DF e Comitê Popular da Copa-DF) em suas fanpages no período de junho de 2013? Para responder a essas perguntas, observamos como o Facebook foi utilizado como ferramenta de mobilização política nas Jornadas de Junho em Brasília.

Conjuntamente, utilizamos a pesquisa quantitativa no levantamento de dados em torno de compartilhamento de postagens no Facebook das fanpages dos grupos políticos, nesse caso escolhidas a priori são: Movimento Passe Livre (MPL) do DF e Comitê Popular da Copa DF. Também buscamos entender como se deu a formação dos eventos de duas formas: primeiro, fazendo análise quantitativa para mostrar a evolução no número de pessoas confirma-

3 Esse acesso é referente aos eventos e o número de pessoas confirmadas; pessoas que disseram que talvez fossem comparecer; e de pessoas convidadas. das nos eventos e o número de pessoas convidadas; e, em segundo lugar, procuramos entrevistar os organizadores dos eventos online. Este estudo é baseado numa análise de conteúdo, e, no que diz respeito ao caráter de pesquisa quantitativa, refere-se às tabelas contidas no corpo do artigo que foram resultado da pesquisa empírica realizada.

Não foi nossa proposta mensurar o impacto do online no offline, mas, apenas, demonstrar como as mobilizações online poderiam ter influenciado na quantidade de manifestantes que foram às ruas no período de tempo em estudo. No entanto, tivemos a preocupação de mostrar a variedade de usos que o Facebook teve para alguns ativistas independentes e movimentos sociais em Brasília. Para esse fim, escolhemos as fanpages: Movimento Passe Livre (MPL) - DF e Comitê Popular da Copa DF.

A escolha do $M P L-D F$ é justificada pelo protagonismo que esse movimento teve no Brasil, sobretudo em São Paulo, iniciando o estopim e ampliando pautas e atos que culminaram nas Jornadas de Junho de 2013. O Comitê Popular da Copa - DF teve participação ativa durante as Jornadas de Junho em Brasília, de forma que se destacou tanto na esfera online como offline por terem sido criadores de alguns eventos no Facebook, dando suporte a várias pautas de diferentes movimentos sociais. Para completar o estudo, também procuramos entender como ocorreram os eventos de convocação para os atos de junho de 2013 desse período, quem os organizou e qual foi sua evolução no número de acessos.

Delimitamos o recorte espacial e temporal ao Distrito Federal, no mês de junho de 2013. As postagens feitas no Facebook dos dois objetos de estudo, o Comitê Popular da Copa do DF e o MPL-DF, foram estudadas a fim de refletir sobre as articulações online para mobilizações offline e as associações de ativistas independentes às manifestações de junho. Buscamos compreender como se deu a formação dos eventos online desses grupos. E responder às perguntas: quais foram os organizadores ${ }^{4}$ ? Como foi a evolução das confirmações e o número de convidados para os eventos?

Utilizamos as informações disponíveis na linha do tempo (ou timeline) das fanpages no Facebook, no período de junho de 2013. Um dos desafios buscou entrevistar com alguns dos criadores dos eventos que, aparentemente,

\footnotetext{
4 Os eventos no Facebook foram criados por diferentes grupos e ativistas independentes, o que será explicado no item 5.3 deste artigo.
} 
não são filiados a movimentos sociais, mas sim, atores políticos de Brasília e que, por meio de seu próprio perfil no Facebook, criaram eventos, convocando grandes multidões para os atos das Jornadas de Junho de 2013.

Por tratar-se de assunto recente tanto no que tange a metodologia para estudo da mídia social Facebook e no que diz respeito às Jornadas de Junho de 2013, criamos nossa própria metodologia baseada nos estudos de Earl (2010) e Valenzuela (2013) como veremos mais à frente na revisão de literatura. Utilizamos para o estudo de caso proposto, as quinze postagens mais compartilhadas das fanpages escolhidas e os eventos de articulação online para as manifestações offline, analisando os que estiverem disponíveis no Facebook, excluindo apenas os que foram atualizados. Os eventos atualizados consistem naqueles que já tinham data marcada, porém, em alguns eventos criados no Facebook, os organizadores, ao invés de criarem novo evento com nova data e horário, apenas os atualizavam mudando informações em cima do mesmo evento.

Por meio de entrevistas aos organizadores dos eventos criados no Facebook durante as Jornadas de Junho de 2013 no DF, buscamos responder às seguintes perguntas: quais estratégias foram usadas na utilização do Facebook? Poderiam tê-lo utilizado de outra forma ou melhoraria alguma coisa? Qual a importância das articulações online para as mobilizações offline? Como se explica a criação de eventos no Facebook para mobilização dos atos das Jornadas de Junho de 2013, em Brasília, por atores políticos que não fazem parte de movimentos sociais? O Facebook foi tema nas reuniões realizadas por vocês offline? Que outras plataformas foram usadas? Quais foram os resultados esperados? Como vocês mudaram suas estratégias do ano passado para esse ano no Facebook e em outras mídias sociais? Quem era encarregado por alimentar a fanpage no Facebook com conteúdo? Vocês debatiam sobre o que iria para a fanpage? Valendo-nos do recurso de entrevistas, procuramos o contato de pessoas-chave de alguns movimentos sociais em Brasília e de algumas mídias alternativas que cobriram as manifestações em Brasília para saber quais os diversos usos que eles fizeram do Facebook e a importância dessa mídia social durante as Jornadas de Junho de 2013 no DF.

Alguns estudos sobre Internet e política nos ajudaram a entender o ativismo online. Earl (2010), por meio da análise de websites de ativismo, categorizou alguns tipos de ativismo online. Também Valenzuela (2013), foi importante para compreender como os movimentos so- ciais utilizam as mídias sociais como ferramenta de mobilização. Os argumentos apresentados pelo autor indicam relação positiva entre a frequência do uso de mídia social e participação política e explicam, de igual modo, como essa relação ocorre em um contexto de comportamento de protesto. Conforme Valenzuela (2013, p. 921), a relação é explicada de três formas: "informação (fonte), expressar opinião e ativismo (juntar-se a causas e achar informações sobre mobilização na mídia social)”.

\section{Teoria dos movimentos sociais e os novos movimentos sociais}

Temos dois conceitos para movimentos sociais: primeiro, autores da contemporaneidade como Santos (2005) e Touraine (1998) dizem que os movimentos sociais da atual conjuntura são denominados como novos movimentos sociais (NMSs); e, em segundo, temos os movimentos considerados "antigos" os quais não se encaixam no conceito de NMS, e, sim no paradigma marxista do qual a luta de classe é o cerne, agindo como a motivação e sua forma de representação são os sindicatos e os partidos políticos.

Para Touraine (1996, p. 76), a representatividade só existira caso haja "uma forte agregação das demandas provenientes de indivíduos e setores bastante diferentes da vida social". E, só se chegará a uma democracia com bases sociais sólidas quando se levar o princípio, citado anteriormente, ao seu máximo. $\mathrm{O}$ autor acredita que, ao distanciar-se dessa situação, e, partindo da ideia de que os partidos políticos são coalizões de "grupos de interesses”, entende-se que alguns deles, mesmo sendo minoria, possuem a capacidade de fazer a balança inclinar-se de um lado ou do outro, dessa forma, adquirindo influência desvencilhada de sua importância objetiva.

Conforme Touraine (1996, p. 77), a "base mais sólida da democracia consiste na existência de um conflito geral entre atores sociais”. O autor afirma que, na Grã-Bretanha, lugar e palco para as classes sociais e seus conflitos mais palpáveis, a democracia alcançou seus modos mais estáveis. Touraine (1996, p. 78) acrescenta que uma das condições da representatividade constitui a necessidade de "que as categorias sociais sejam capazes de se organizarem de forma autônoma no próprio plano da vida social, portanto, o montante da vida política”.

Dos apontamentos de Touraine (1996) sobre os partidos políticos e classes sociais nas sociedades ocidentais, vemos que: 
Os partidos representaram classes sociais; atualmente, representam sobretudo projetos de vida coletiva, por vezes, até mesmo, movimentos sociais. A própria ideia de classe social tirou sua força da identidade que estabelecia entre uma situação social e um ator, simultaneamente, social e político. Ação de classe e relações sociais de produção não podiam ser dissociadas, como também a direita não podia dissociar ideias liberais e leis do mercado (TOURAINE, 1996, p. 80).

Ainda conforme Touraine (1996, p. 83), tem-se como pressuposto para essa representatividade "que as demandas sociais pretendem ser em si mesmas representáveis, isto é, que aceitem as regras do jogo político e a decisão da maioria”.

Toro (1996, p. 5) conceitua mobilização social como "convocar vontades para atuar na busca de um propósito comum, sob uma interpretação e um sentido também compartilhados". Toro (1996, p. 5) ainda argumenta que participar ou não consiste em uma decisão individual, implica basicamente as pessoas terem a capacidade de ver a si mesmas ou não, como responsáveis e causadores de mudanças.

Conforme Gohn (2014, p. 20), Lorenz von Stein é um dos primeiros a usar o termo "movimento social", quando, em 1842, notou a necessidade de uma ciência que estudasse o socialismo emergente na França, dessa forma, criando significado de uma luta contra a conjuntura. E Gohn (2014, p. 20) acrescenta que alguns dos estudos que foram pioneiros nessa área tinham como "objeto central ações sociais coletivas similares aos movimentos sociais da atualidade referiam-se a eles como distúrbios populares”.

No estudo de movimentos sociais, alguns estudiosos tiveram influência em Freud no que concerne a teoria de agressão instintiva. Assim temos:

H. Taine foi o primeiro a discutir o comportamento das massas, dando-lhe um tratamento psicológico baseado em instintos selvagens da natureza humana - com isto ele fez uma descrição pitoresca das revoltas revolucionárias. Taine forjou os princípios que foram trabalhados depois por Tarde, e Le Bom faz uma análise bastante conservadora, assim como Ortega y Gasset. Eles deram elementos para uma teoria baseada no comportamento tido como irracional das massas. Foram influenciados por Freud - teoria da agressão instintiva, que tratou dos instintos selvagens de sobrevivência. As explicações sobre os impulsos violentos e a propensão á agressão também se alicerçaram em Darwin. Desvios do comportamento e frustrações explicavam o comportamento das lideranças das ações (GOHN, 2014, p. 20).
O estudo das ações sociais para Sztompka (1998 apud GOHN, 2014, p. 21) acredita que "as entidades sociais complexas que aparecem no transcurso da história humana não são mais que produtos acumulados e duradouros das ações sociais. Explicar tais entidades significa rastrear suas raízes nas ações humanas; explicar as ações (compreende-las) [...]”.

No contexto da atual conjuntura, em Gohn (2011, p. 342-343) temos que, dadas as circunstâncias nas quais as políticas neoliberais avançaram, alguns movimentos sociais começaram a emergir como, por exemplo, contra as reformas estatais, a Ação da Cidadania contra a Fome e outros. Dentro de algumas categorias profissionais, as lutas surgiram no contexto de crescimento da economia informal, como no caso dos transportes urbanos, em que os transportes alternativos (perueiros) surgiram. Ainda para Gohn (2011, p. 343), entende-se que: "Algumas dessas ações coletivas surgiram como respostas à crise socioeconômica, atuando mais como grupos de pressão do que como movimentos sociais estruturados. Os atos e manifestações pela paz, contra a violência urbana, também são exemplos dessa categoria”.

\section{Redes sociais virtuais e os movimentos sociais}

O Facebook foi criado por Mark Zuckerberg, em outubro de 2003. Ainda era estudante em Harvard, quando invadiu um ID do banco de dados da universidade e criou o Facemash. Tratava-se de um site em que era possível aos alunos comparar duas fotografias de identidade e eleger a que considerassem mais atrativa. Com a intenção de evitar problemas jurídicos, Mark criou o Facebook.

As estatísticas do Socialbakers (2014) sobre o $\mathrm{Fa}$ cebook Brasil revelam que o grupo mais amplo demograficamente tem entre 18 e 24 anos de idade, seguido pelos usuários que tem entre 25 e 34 . O número de usuários do sexo masculino é de $47 \%$ e feminino $53 \%$, comparado com $75 \%$ e $25 \%$ na Índia e $59 \%$ e $41 \%$ na Indonésia.

Estudar redes sociais virtuais, como o Facebook, tem relevância para as Ciências Sociais e a Comunicação Social ambas examinam como se dão as relações entre mídias sociais e pessoas engajadas com atividades políticas nesse novo contexto virtual. Conforme Pearce \& Kendzior (2012 apud VALENZUELA, 2013, p. 922), existem muitas evidências de que pessoas envolvidas em atividades cívicas e políticas, incluindo comportamento de protesto, são habitualmente 
usuários de mídias sociais, isso ocorre tanto em países desenvolvidos como em países em desenvolvimento.

Telles (2010, p. 78) considera as redes sociais como parte das mídias sociais, e os sites de relacionamento entram também como rede social. Majoritariamente as grandes redes sociais, como, o Facebook, agregam milhares de pessoas de usuários, que após terem se cadastrado podem exibir seu perfil com fotos, textos, mensagens, vídeos e dados pessoais. Para cada rede, há suas próprias regras, o que influencia a forma do comportamento de seus usuários $\mathrm{e}$ decide qual o formato mais eficiente de interação. Nesse caso, a própria rede social oferece ferramentas como busca e apenas usuários podem ter acesso às informações disponíveis na rede social, conforme Telles (2010, p. 78-79). Essas redes sociais permitem a interação de diversas formas, até mesmo a interação com outras, como por exemplo, $\mathrm{Fa}$ cebook com Twitter, Facebook com Instagram.

No Facebook, vários movimentos sociais têm aberto suas fanpages e possuem milhares de seguidores, como, por exemplo, Movimento dos Trabalhadores Sem Teto (MTST) que possui 41.217 curtidas; Movimento dos Trabalhadores Sem Terra (MST) 181.413 curtidas; MPL com 16.000 curtidas.

Os movimentos sociais têm utilizado, na atualidade, as redes sociais por meio das mídias sociais para articular as pessoas para as mobilizações offline. Nessa perspectiva, cita-se Gohn (2011), em relação ao movimento social e aos novos meios de comunicação e informação:

\begin{abstract}
Nós os encaramos como ações sociais coletivas de caráter sociopolítico e cultural que viabilizam formas distintas de a população se organizar e expressar suas demandas. Na ação concreta, essas formas adotam diferentes estratégias que variam da simples denúncia, passando pela pressão direta (mobilizações, marchas, concentrações, passeatas, distúrbios à ordem constituída, atos de desobediência civil, negociações etc.) até as pressões indiretas. $\mathrm{Na}$ atualidade, os principais movimentos sociais atuam por meio de redes sociais, locais, regionais, nacionais e internacionais ou transnacionais, e utilizam-se muito dos novos meios de comunicação e informação, como a internet. Por isso, exercitam o que Habermas denominou de o agir comunicativo. A criação e o desenvolvimento de novos saberes, na atualidade, são também produtos dessa comunicabilidade (GOHN, 2011, p. 335-336).
\end{abstract}

Para Bimber et al. (2012, p. 5), as ferramentas para organizar ações coletivas agora estão ao alcance de pessoas e grupos semiformais ou informais por meio das tecnologias, a ação coletiva pode nascer daqueles que têm interesses e objetivos compartilhados sem, necessariamente, obter custos com os aparatos organizacionais clássicos que tradicionalmente tem servido para facilitar o compartilhamento das ações. A utilização das mídias sociais foi de extrema importância tanto na mobilização das manifestações de junho e julho de 2013 no Brasil, como ao redor do mundo.

As ações coletivas (organizadas por movimentos sociais, ativistas e, no Brasil, no ano passado nas jornadas de junho, feitas por cidadãos comuns que não haviam participado de protestos antes) têm adquirido um caráter mais informal no que diz respeito a mobilizações online para ações offline. Bimber et al. (2012, p. 3) manifestam que alguns acadêmicos, no que concerne a várias instâncias das ações coletivas, sofrem falta de um comando organizacional, como também de identidade e de acordo ideológico.

Conforme Bimber et al. (2012, p. 5), as ferramentas para organizar ações coletivas agora estão ao alcance de pessoas e grupos semiformais ou informais, por meio das tecnologias. A ação coletiva pode nascer daqueles que têm interesses e objetivos compartilhados sem, necessariamente, obter custos com os aparatos organizacionais clássicos que tradicionalmente têm servido para facilitar o compartilhamento das ações. Assim entende-se que a utilização das mídias sociais foi de extrema importância tanto na mobilização das manifestações das jornadas de junho e julho de 2013 no Brasil, como ao redor do mundo. Isso foi comprovado pela pesquisa feita pelo IBOPE (2014) e pelos relatos que Castells (2013) dá sobre a Primavera Árabe, na qual as mídias sociais tiveram papel fundamental.

$\mathrm{Na}$ conjuntura atual, os novos movimentos sociais em rede como designados por Gohn (2007), Scherer-Warren (2006) e Castells (2012) articulam-se para realizar mobilizações, almejando alvos comuns. A convocação para as ações offline ocorre online. Como, por exemplo, em Brasília no dia 19 de junho de 2013, quando o MPL criou o evento no Facebook para a mobilização offline, que ocorreria em Brasília, e também os eventos do Comitê Popular da Copa.

Conforme Pallota (1964 apud PATRÍCIO, 1998), "grupo de pressão" seria definido como:

Organizações, entes, instituições que, diante dos próprios interesses inseridos em uma estratégia mais ou menos vasta, intervêm - exercitando a influência que possuem ou pressionando - nas atividades dos partidos, dos homens políticos, no governo, no parlamento, e em outras assembleias e centros de poder político, com o fim de obter uma particular política ou específica ação e iniciativa em próprio favor, ou conseguir influenciar uma decisão importante. (PALLOTA, 1964 apud PATRÍCIO, 1998, p. 22). 
Para obter o que almejam, os grupos de pressão podem agir via ação direta, de acordo com Patrício (1998, p. 26), esta "acontece quando a fase de pedido e ameaça é feita diretamente pelo grupo interessado contras os homens do poder oficial, isto é, a ação é entre opressor e oprimido". Assim o que vimos em junho de 2013 foi a ação direta dos grupos de pressão como Movimento Passe Livre e Comitê Popular da Copa e tantos outros que compuseram as manifestações nas ruas. Por outro lado, temos a ação indireta que é definida por Patrício (1998, p. 28), quando o alvo é avisado sem estar presente nas ações do grupo de pressão. No entanto, nota vários acontecimentos em torno de si mesmo, tendo que decifrá-los para chegar a uma dedução que pode ser mais ou menos nítida.

A pressão indireta para Patrício (1998, p. 29) faz uso especialmente dos meios de comunicação, com publicações periódicas e propaganda. Esses podem ser considerados persuasivos ou enganadores, como, por exemplo, o uso da censura que consiste em uma "manipulação direta", para assim conseguir o domínio da opinião pública. Então, a ação indireta dos grupos de pressão de junho de 2013 se deu por meio das mídias sociais que exerceram essa pressão sobre diversos usuários e redes dentro das mídias, e a pressão direta se deu nas ruas. Compreendemos que a pressão do governo foi direta como no caso dos seis ativistas do Black Blocs ${ }^{5}$ (os administradores e um criador de conteúdos para página do Facebook), que foram presos por incitação à violência e formação de quadrilha).

Sobre as associações voluntárias, o autor Truman apud Olson (2011, p. 141) tem a visão de que "à medida que começam a surgir problemas que os pequenos grupos primários já não podem administrar surgirão grandes associações voluntárias para lidar com eles”.

Conforme Valenzuela (2013), as explicações existentes para a relação positiva entre a frequência do uso de mídia social e participação política em um contexto de comportamento de protesto são elencadas da seguinte maneira: primeiramente, o uso das mídias sociais como fonte de informações; depois expressar opinião política; e juntar-se a causas para obter informação sobre mobilização.

Valenzuela (2013) comenta sobre o uso das mí-

\footnotetext{
5 Ativistas do Black Bloc são presos e justiça do Rio de Janeiro proíbe uso de máscaras em manifestações. Disponível em: $<$ http://agenciapulsar.org/brasil2013/movimentos-sociais/ ativistas-do-black-bloc-sao-presos-pela-justica-do-rio-de-janeiro-policia-tem-acesso-a-informacoes-pelo-facebook/>. Acesso em: 02 jun. 2014.
}

dias sociais com o objetivo de buscar notícias, como, por exemplo, seguir o perfil da BBC no Twitter, ou até mesmo, ser exposto a uma notícia na linha do tempo do Facebook em que um amigo compartilhou um link de notícia. Nos dois casos apresentados, o aprendizado teria lugar para colaborar com o aumento da chance de uma ação política segundo Valenzuela (2013, p. 923).

Em seu estudo, Valenzuela (2013) coleta dados no Chile durante os protestos de 2011. Revela que no Chile os protestos do inverno de 2011 tiveram manifestações não usuais com pautas variadas, remete aos acontecimentos no Brasil, nos atos de junho de 2013 como veremos mais a fundo posteriormente. Dos resultados da pesquisa, ele obteve:

Como esperado, quanto maior o uso de plataformas de mídias sociais maior seria o uso de mídia social para informação, expressar opinião, e juntar-se a causas sociais. Por sua vez, quando se tratava de expressar opinião e juntar-se a causas sociais por meio de plataformas de mídia social o uso foi positivo e significante, também associado à participação de atividades de protesto. Embora o uso de mídias sociais para notícias não seja relacionado ao comportamento de protesto, uma vez que outras variáveis foram levadas em consideração, as três atividades de mídia social inclusas no modelo mediaram, totalmente, os efeitos direitos sobre um uso geral de mídia social nos protestos (VALENZUELA, 2013, p. 935, tradução nossa).

Merece destaque o fato de que tanto em países desenvolvidos como em países em desenvolvimento, um aspecto a ser levantado é: "Existem várias evidências que apontam, que tanto em países desenvolvidos e em desenvolvimento, as pessoas que se engajam em atividades civis e políticas $\bigotimes$ incluindo comportamento de protesto $\bigotimes$ são usuários frequentes de mídias sociais" (VALENZUELA, 2012 apud VALENZUELA et al., 2013, tradução nossa). O que é comprovado com base nos protestos de junho de 2013, em que o IBOPE (2014) constata que mais de 70\% dos manifestantes tomam ciência a com base nas mídias sociais.

\section{Jornadas de junho de 2013}

Nos atos de junho de 2013, movimentos como MPL, com sua pauta de tarifa zero e melhoria do transporte público, abriu-se espaço para outras pautas e movimentos, foi como o estopim. Pessoas que sequer eram afiliadas a outros movimentos se juntaram voluntariamente e acrescentaram outras pautas às manifestações. Assim como outros movimentos sociais e organizações também se juntaram para dar peso às mobilizações. 
Resgatando Lincoln em Maricato et al. (2013), desde 1992 as manifestações não eram tão amplas e generalizadas de cima a baixo no Brasil, então, por meio dos dados que a Folha São Paulo divulgou sobre as Jornadas de Junho, foi constatado que $53 \%$ dos manifestantes tinham menos de 25 anos e $71 \%$ participavam de uma manifestação pela primeira vez em sua vida.

Conforme Gohn (2013, p. 8), "estima-se que cerca de dois milhões de pessoas saíram às ruas do país entre junho e agosto de 2013, em 483 municípios, para protestar na condição de cidadão indignado contra tarifa de ônibus e a qualidade de vida urbana”.

Para Singer (2013), os acontecimentos das jornadas de junho se dividem em três etapas. Primeiramente teria sido iniciada por uma pequena fração da classe média, por meio de mobilizações na cidade de São Paulo nos dias 5, 10,11 e 13 de junho. Nesse momento, a pauta era a redução da tarifa das passagens do transporte público, seguindo o modelo do Movimento Passe Livre ${ }^{6}$ (MPL) em anos anteriores. As mobilizações foram convocadas nas redes sociais e os protestantes paralisavam as vias públicas por grandes períodos de tempo. Da primeira para a segunda jornada, aumentava o número de manifestantes, por volta de dois mil para cinco mil pessoas.

Na terceira convocação do MPL, dia 11, a audiência foi novamente de cinco mil pessoas, em que houve um cenário de violência policial e alguns grupos de jovens destruíram patrimônios. No dia 13, segundo os organizadores reuniram-se vinte mil pessoas, de acordo com a polícia militar (PM) cinco mil, houve uma marcha da rua Conso-

6 O MPL "é um movimento social autônomo, apartidário, horizontal e independente, que luta por um transporte público de verdade, gratuito para o conjunto da população e fora da iniciativa privada" (MOVIMENTO PASSE LIVRE, 2011). Sua história foi iniciada ou mais conhecida como o batizado do MPL numa Plenária Nacional pelo Passe Livre, no de 2005, em Porto Alegre. Algum tempo antes disso, seis anos antes, a Campanha pelo Passe Livre já existia em Florianópolis. Dois fatos históricos são fundamentais na atuação e raiz do MPL como: Revolta do Buzu em Salvador, em 2003 e as Revoltas da Catraca em Florianópolis nos anos de 2004 e 2005. E, já no ano de 2006 o MPL veio a realizar o seu Terceiro Encontro Nacional, contando com a presença de mais de 10 cidades brasileiras, realizado em escola do MST (Movimento dos Trabalhadores Rurais Sem Terra). O movimento é caracterizado pela independência de organizações externas e financiamentos que requeiram algo em troca, e suas regras são escolhas e criação das pessoas envolvidas diretamente em sua luta, conforme (MOVIMENTO PASSE LIVRE, 2011). lação rumo à Paulista, mas impedidos de prosseguirem a marcha pacífica tornou-se em um ato de repressão violenta por parte da PM, pois atingiu transeuntes e jornalistas indiscriminadamente, conforme Singer (2013).

O MPL, organização horizontal e autonomista, porém dirigente, foi o estopim das Jornadas de Junho que dos “ $R \$ 0,20$ ” foram para tantas outras pautas, e as manifestações depois se tornaram heterogêneas, mas também tendo o apoio desse movimento. A causa tão lutada pelo Passe Livre teve voz em mais de cem cidades:

Tomando as ruas, as Jornadas de Junho de 2013 rasgaram toda e qualquer perspectiva técnica acerca das tarifas e da gestão dos transportes que procurasse restringir seu entendimento aos especialistas e sua "racionalidade", a serviço dos de cima. Ao reverter o aumento das passagens em mais de cem cidades do país, as pessoas deslocaram momentaneamente - e com impactos duradouros - o controle político da gestão do transporte. Forjou-se, no calor das barricadas, uma experiência de apoderamento que não se resume à ocupação física das cidades, mas estende-se à maneira como se organizam os transportes no país. É essa tomada de poder que assusta os gestores estatais e privados, que tentam agora reocupar o espaço que perderam para os trabalhadores urbanos. Movimento Passe Livre (MARICATO et al., 2013, p. 17).

No caso do Brasil, a autora Gohn (2013, p. 9) classifica os atos de protesto de junho a agosto de 2013 como não nacionalistas, e sim como uma maneira de agir coletivamente por meio das redes sociais e telefonia móvel, uma vez que pessoas sem nenhuma filiação a partidos políticos e não militantes de movimentos sociais participaram das jornadas de junho e julho de 2013, conforme pesquisa do IBOPE (2014). A peculiaridade dessas manifestações em 2013 foi a sua organização horizontalizada, descentralizada, construindo o que Gohn chamaria de "outra estética" de manifestação. Essas características podem ser bem notórias quando pensamos no coletivo Movimento Passe Livre (MPL), que possui uma liderança horizontal e descentralizada e que usou como forma de convocação para as manifestações a rede social virtual Facebook.

Segundo Castells (2013, p. 122), o mundo inteiro presenciou ondas de protestos das mais variadas ordens, e as ruas foram tomadas por movimentos como Ocuppy Wall Street e a Primavera Árabe. Nesse contexto, o papel que as mídias sociais exerceram foi fundamental para o aumento das mobilizações. Castells (2013, p. 122) disse que, após a ascensão do Tea Party nos Estados Unidos, manifestantes 
inspirados por ideais libertários e populistas foram às ruas expressar sua indignação, pois havia uma quantidade significativa de opositores ao governo do presidente Obama. A convocação para a manifestação do dia 17 de setembro aconteceu no dia 13 de junho de 2011, por meio de uma revista de crítica cultural no blog Adbusters. A partir de então, foi lançada a hashtag “\#ocuppywallstret”. Dessa maneira, podemos ver que não só no Brasil ocorreram essas ondas de manifestações, pois era global a tendência.

\section{Facebook e as Jornadas de Junho de 2013 no Distrito Federal}

\subsection{Movimento Passe Livre-DF}

O MPL-DF durante as Jornadas de Junho de 2013 teve doze postagens em sua fanpage, por isso não foi possível estudar quinze postagens como estava definido no começo deste estudo. Enquanto o Passe Livre SP, a fanpage do MPL-SP, teve um total de 57 postagens no mês de junho, em 2013. Abaixo temos uma tabela apresentando as postagens do mês de junho do MPL-DF.

Tabela 1- Postagens do mês de junho de 2013, da fanpage do MPL-DF

\begin{tabular}{c|c|c|c|l|c}
\hline $20 / 06$ & 0 & 2 & 5 & $\begin{array}{l}\text { Link para artigo da } \\
\text { Carta Capital que } \\
\text { abordava um atropela- } \\
\text { mento de manifestante } \\
\text { durante uma mani- } \\
\text { festação. }\end{array}$ & $\begin{array}{c}\text { Debate } \\
\text { político }\end{array}$ \\
\hline $21 / 06$ & 1 & 2 & 37 & $\begin{array}{l}\text { Nota de divulgação da } \\
\text { Marcha das Vadias, que } \\
\text { ocorreria um dia após a } \\
\text { postagem. }\end{array}$ & $\begin{array}{c}\text { Apoio a outra } \\
\text { organização }\end{array}$ \\
\hline $23 / 06$ & 2 & 2 & 0 & $\begin{array}{l}\text { Post sobre evento } \\
\text { criado pelo MPL-DF } \\
\text { para reunião e oficina } \\
\text { do MPL. }\end{array}$ & Mobilização \\
\hline $24 / 06$ & 0 & 1 & 12 & $\begin{array}{l}\text { Carta aberta do MPL- } \\
\text { São Paulo à Presidenta. }\end{array}$ & $\begin{array}{c}\text { Debate } \\
\text { politico }\end{array}$ \\
\hline $25 / 06$ & 1 & 4 & 11 & $\begin{array}{l}\text { Compartilhamento do } \\
\text { evento II Protesto em } \\
\text { Taguatinga, organiza- } \\
\text { do pelo Comitê Popular } \\
\text { da Copa DF. }\end{array}$ & Mobilização \\
\hline $29 / 06$ & 0 & 0 & $\begin{array}{l}\text { Link para blog com } \\
\text { texto do professor } \\
\text { Paulo Cesar, professor } \\
\text { da UnB, falando sobre } \\
\text { a tarifa zero. }\end{array}$ & político \\
\hline & Fonte: Fanpage do MPL no Facebook \\
\hline MPate
\end{tabular}

Durante junho de 2013, na administração ${ }^{7}$ da fanpage do MPL-DF, havia por volta de quatro pessoas colocando conteúdo online. Segundo R. Santos (2014, grifo nosso), membro do MPL-DF, disse em entrevista, o movimento não tem tanto impacto pelo Facebook, não apostam na mobilização online da mesma forma como nas mobilizações por meio de trabalho de base já existente do MPL-DF no âmbito offline.

No dia 12/06, os três comentários são sobre os atos do MPL em Brasília, uma internauta pergunta quando ocorreria um próximo protesto, em seguida outra pessoa responde com um link para o evento, e a terceira pessoa faz convite para que as pessoas compareçam no evento e coloca a pauta de manifestação, nesse caso a PEC 37. Os comentários do dia 13/06 são sobre questionamento de uma pessoa sobre quando ocorreriam os atos em Brasília, em seguida o MPL-DF sana as dúvidas e coloca em resposta link dos eventos, outra pessoa divulgando protesto do dia 26/06/13 e sua pauta.

No que se refere aos comentários do dia 14/06, o primeiro foi usado pelo MPL-DF para marcar as fanpages do MPL de outras localidades, o segundo de um usuário do FB para marcar um amigo, e o outro para divulgar

\footnotetext{
7 Os dados apresentados sobre a administração foram concedidos em entrevista dada por Silva (2014).
} 
a manifestação do dia 26/06 e sua respectiva pauta. Nos comentários do dia 19/06, a maioria foi compartilhando links com assuntos relacionados a transporte e dois dando suporte a luta Tarifa Zero. No dia 24/06, o único comentário foi para acordar com o post do MPL-DF e compartilhar um link de assunto relacionado a transporte. Seguindo um padrão semelhante no dia 25/06, um comentário foi compartilhando link relacionado a transporte, dois dando suporte à manifestação e outro compartilhando um manifesto popular (esse feito por outra fanpage).

Dos doze posts temos que: cinco foram sobre debate político, 9\% de denúncia, quatro de mobilização e dois de apoio à outra organização. No mês de junho, o MPL - DF pelo que podemos compreender teve como uma de suas estratégias para provocar o debate político por meio do Facebook. Em entrevista, o representante R. Santos (2014, grifo nosso) do MPL-DF disse que a mobilização do movimento para eventos offline é feita pelos contatos de base, e que seria importante mesclar a mobilização offline, como, por exemplo, por meio de panfletagem e os eventos no Facebook, com a finalidade de abarcar outros públicos que não alcançariam no offline.

As publicações com mais compartilhamentos foram sobre debate político e de apoio à outra organização que nesse caso seria o MPL - SP. As mais curtidas foram também de apoio à outra organização e de debate político, seguidas pelas categorias de mobilização e denúncia.

Além da fanpage no Facebook, o MPL-DF utiliza outras ferramentas como o we.raiseup para comunicação interna do grupo e e-mail para comunicação externa.

\subsection{Comitê Popular da Copa DF}

Tabela 2 - Postagens do mês de junho de 2013, da fanpage do Comitê Popular da Copa-DF (continua na próxima página)

\begin{tabular}{c|c|c|c|c|c}
\hline Dia / Mês & $\begin{array}{c}\mathbf{N}^{\circ} \text { de com- } \\
\text { partilha- } \\
\text { mentos }\end{array}$ & $\begin{array}{c}\mathbf{N}^{\circ} \text { de } \\
\text { comentá- } \\
\text { rios }\end{array}$ & $\begin{array}{c}\mathbf{N}^{\circ} \text { de } \\
\text { curtidas }\end{array}$ & \multicolumn{1}{|c|}{ Conteúdo } & Categoria \\
\hline $04 / 06$ & 11 & 1 & 7 & $\begin{array}{l}\text { Daeventos, e foto fazendo } \\
\text { comparação entre a ditadura } \\
\text { e a democracia. }\end{array}$ & $\begin{array}{c}\text { Debate } \\
\text { político }\end{array}$ \\
\hline $05 / 06$ & 11 & 1 & 13 & $\begin{array}{l}\text { Debate político sobre me- } \\
\text { e abaixo assinado da 0NG } \\
\text { Rodas da Paz. }\end{array}$ & Apoio à outra \\
organização
\end{tabular}

\begin{tabular}{|c|c|c|c|c|c|}
\hline $12 / 06$ & 361 & 1 & 98 & $\begin{array}{l}\text { Lançamento da campanha } \\
\text { "Cartão Vermelho para a } \\
\text { Copa", e fotografia } 1 .\end{array}$ & $\begin{array}{l}\text { Debate } \\
\text { político }\end{array}$ \\
\hline $13 / 06$ & 35 & 2 & 49 & $\begin{array}{l}\text { Lançamento da campanha } \\
\text { "Cartão Vermelho para a } \\
\text { Copa", e fotografía } 2 .\end{array}$ & $\begin{array}{l}\text { Debate } \\
\text { político }\end{array}$ \\
\hline $13 / 06$ & 551 & 7 & 91 & $\begin{array}{l}\text { Lançamento da campanha } \\
\text { "Cartão Vermelho para a } \\
\text { Copa", e fotografia } 3 .\end{array}$ & $\begin{array}{l}\text { Debate } \\
\text { político }\end{array}$ \\
\hline $14 / 06$ & 96 & 1 & 38 & $\begin{array}{l}\text { Lançamento da campanha } \\
\text { "Cartão Vermelho para a } \\
\text { Copa", e fotografia } 4 .\end{array}$ & $\begin{array}{l}\text { Debate } \\
\text { político }\end{array}$ \\
\hline $15 / 06$ & 21 & 2 & 18 & $\begin{array}{l}\text { Denúncia sobre repressão } \\
\text { policial durante as manifes- } \\
\text { taçōes de junho em Brasília } \\
\text { ocorridas até a data presente } \\
\text { do post. }\end{array}$ & Denúncia \\
\hline $16 / 06$ & 3 & 0 & 5 & $\begin{array}{l}\text { Vídeo de denúncia sobre } \\
\text { truculência policial. }\end{array}$ & Denúncia \\
\hline $16 / 06$ & 1 & 0 & 13 & $\begin{array}{l}\text { Fotos do ato do dia } 15 \text { de } \\
\text { junho. }\end{array}$ & Mobilização \\
\hline 19/06 & 5 & 0 & 16 & $\begin{array}{l}\text { \#Copapraquem? Foto da } \\
\text { campanha cartão vermelho } \\
\text { para a copa com pauta contra } \\
\text { a criminalização da infância e } \\
\text { adolescência. }\end{array}$ & $\begin{array}{l}\text { Debate } \\
\text { político }\end{array}$ \\
\hline $22 / 06$ & 41 & 1 & 26 & $\begin{array}{l}\text { Nota sobre Dilma Roussef } \\
\text { alegando que a presidenta } \\
\text { mentiu em cadeia nacional. }\end{array}$ & $\begin{array}{l}\text { Debate } \\
\text { político }\end{array}$ \\
\hline $24 / 06$ & 2 & 0 & 6 & $\begin{array}{l}\text { Denúncia sobre torcedores } \\
\text { proibidos de entrar em jogo } \\
\text { da FIFA por vestirem camisas } \\
\text { com frases escritas. }\end{array}$ & Denúncia \\
\hline $26 / 06$ & 3 & 0 & 7 & $\begin{array}{l}\text { Convite do Comitê Popular da } \\
\text { Copa para os usuários do Fa- } \\
\text { cebook participarem da cam- } \\
\text { panha Cartão vermelho para a } \\
\text { Copa mandando uma foto. }\end{array}$ & Mobilização \\
\hline $28 / 06$ & 3 & 0 & 7 & $\begin{array}{l}\text { Nota convocatória para } 0 \text { ato } \\
\text { do dia 30/06. }\end{array}$ & Mobilização \\
\hline $30 / 06$ & 1 & 0 & 2 & $\begin{array}{l}\text { Link para assistir a } \\
\text { manifestação ao vivo. }\end{array}$ & $\begin{array}{c}\text { Mobilização } \\
\text { (em tempo } \\
\text { real) }\end{array}$ \\
\hline
\end{tabular}


Tabela 2 - postagens do mês de junho de 2013, da fanpage do Comitê Popular da Copa-DF (continuação da página anterior)

\begin{tabular}{|c|c|c|c|c|c|}
\hline Dia / Mês & $\begin{array}{l}\mathrm{N}^{\circ} \text { de com- } \\
\text { partilha- } \\
\text { mentos }\end{array}$ & $\begin{array}{l}\mathrm{N}^{\circ} \text { de co- } \\
\text { mentários }\end{array}$ & $\begin{array}{c}N^{\circ} \text { de cur- } \\
\text { tidas }\end{array}$ & Conteúdo & Categoria \\
\hline $12 / 06$ & 361 & 1 & 98 & $\begin{array}{l}\text { Lançamento da campanha } \\
\text { "Cartão Vermelho para a } \\
\text { Copa", e fotografia } 1 .\end{array}$ & Debate político \\
\hline $13 / 06$ & 35 & 2 & 49 & $\begin{array}{l}\text { Lançamento da campanha } \\
\text { "Cartão Vermelho para a } \\
\text { Copa", e fotografia } 2 .\end{array}$ & Debate político \\
\hline $13 / 06$ & 551 & 7 & 91 & $\begin{array}{l}\text { Lançamento da campanha } \\
\text { "Cartão Vermelho para a } \\
\text { Copa", e fotografia } 3 .\end{array}$ & Debate político \\
\hline $14 / 06$ & 96 & 1 & 38 & $\begin{array}{l}\text { Lançamento da campanha } \\
\text { "Cartão Vermelho para a } \\
\text { Copa", e fotografia } 4 .\end{array}$ & Debate político \\
\hline $15 / 06$ & 21 & 2 & 18 & $\begin{array}{l}\text { Denúncia sobre repressão } \\
\text { policial durante as manifes- } \\
\text { tações de junho em Brasília } \\
\text { ocorridas até a data presen- } \\
\text { te do post. }\end{array}$ & Denúncia \\
\hline $16 / 06$ & 3 & 0 & 5 & $\begin{array}{l}\text { Vídeo de denúncia sobre } \\
\text { truculência policial. }\end{array}$ & Denúncia \\
\hline $16 / 06$ & 1 & 0 & 13 & $\begin{array}{l}\text { Fotos do ato do dia } 15 \text { de } \\
\text { junho. }\end{array}$ & Mobilização \\
\hline $19 / 06$ & 5 & 0 & 16 & $\begin{array}{l}\text { \#Copapraquem? Foto da } \\
\text { campanha cartão vermelho } \\
\text { para a copa com pauta } \\
\text { contra a criminalização da } \\
\text { infância e adolescência. }\end{array}$ & Debate político \\
\hline $22 / 06$ & 41 & 1 & 26 & $\begin{array}{l}\text { Nota sobre Dilma Roussef } \\
\text { alegando que a presidenta } \\
\text { mentiu em cadeia nacional. }\end{array}$ & Debate político \\
\hline $24 / 06$ & 2 & 0 & 6 & $\begin{array}{l}\text { Denúncia sobre torcedores } \\
\text { proibidos de entrar em jogo } \\
\text { da FIFA por vestirem camisas } \\
\text { com frases escritas. }\end{array}$ & Denúncia \\
\hline $26 / 06$ & 3 & 0 & 7 & $\begin{array}{l}\text { Convite do Comitê Popular } \\
\text { da Copa para os usuários do } \\
\text { Facebook participarem } \\
\text { da campanha Cartão verme- } \\
\text { lho para a Copa mandando } \\
\text { uma foto. }\end{array}$ & Mobilização \\
\hline $28 / 06$ & 3 & 0 & 7 & $\begin{array}{l}\text { Nota convocatória para } 0 \text { ato } \\
\text { do dia } 30 / 06 \text {. }\end{array}$ & Mobilização \\
\hline $30 / 06$ & 1 & 0 & 2 & $\begin{array}{l}\text { Link para assistir a mani- } \\
\text { festação ao vivo. }\end{array}$ & $\begin{array}{c}\text { Mobilização (em } \\
\text { tempo real) }\end{array}$ \\
\hline
\end{tabular}

As três primeiras postagens foram iguais no seu formato textual que falava sobre a campanha do cartão vermelho contra a copa, exceto pela foto, que em cada um eram diferentes pessoas e diferentes temas abordados. Observa-se que o número de compartilhamentos é bem diferente, no dia 12/06 o post obteve 361 compartilhamentos, no dia 13/06 obtiveram 551 e 35 compartilhamentos.

A maioria dos comentários feitos em postagens aparentava ter a postura de concordar com o conteúdo e dar apoio à pauta que estava sendo colocada; outros comentários que também apareceram foram para marcar pessoas no post, e, provavelmente, com a finalidade de que a pessoa que foi marcada lesse o post.

Dos 15 posts temos que: sete foram sobre debate político, três de denúncia, quatro de mobilização e um de apoio à outra organização. $\mathrm{O}$ debate político teve maior porcentagem de postagens, o que é compatível com o que o representante do Comitê Popular da Copa - DF disse em entrevista Silva (2014, grifo nosso):

A importância é central, porque é a principal forma de comunicação que a gente tem com as pessoas em geral. Os movimentos sociais eles têm uma dificuldade para ter eco, para ter voz. Os meios de comunicação tradicional não dão espaço para isso, e quando dão espaço nem sempre é da melhor forma possível, é um tempo muito curto, ou então com recortes que distorcem totalmente o que a gente quer colocar. A Internet é o único meio, na realidade, que podemos colocar o que pensamos na íntegra, e de forma aberta e ampla. Não só para o Comitê Popular da Copa, para todo mundo que se envolve com militância política acaba sendo um espaço central para mobilização, para disputa ideológica. (informação verbal)

O Facebook constitui uma mídia social, na qual os movimentos sociais têm espaço para dizer seu posicionamento político sem distorções da grande mídia. Assim temos que além da mobilização e outros fins que o Facebook pode ter o espaço para colocar abertamente o debate político e, como comenta Amaral sobre as jornadas de junho de 2013:

O fato novo, portanto, não é a existência da estrutura eletrônica explorada, ela está aí faz anos, e inexistiu no maio de 1968, mas a transformação qualitativa de seu uso, deixando de ser, entre nós, tão-só, o veículo quase mágico que dá suporte ao correio eletrônico ou às salas de bate papo. Como fator mobilizador, aliás, ela já havia demonstrado suas possibilidades na 'primavera árabe' e na contestação a Wall Street. Mas, penso que entre nós, para além desse seu papel mobilizador, a rede, principalmente em função da falência ética dos grandes meios, passou a constituir-se no mais importante - porque pulverizado e até aqui não controlado - órgão de nossa imprensa, realmente livre, livre de controle ideológico porque permeada por todas as tendências do pensamento, e assim apta a veicular todas as opiniões, o que enseja o debate vedado pela imprensa ideologicamente monopolista. Conforme Roberto Amaral (SOUSA et al, 2013, p. 11) 


\subsection{Eventos no Facebook das manifestações de Brasília}

A criação de eventos no Facebook durante o período inicial de protestos nas ruas em junho de 2013, não foi tão intenso. Depois houve crescimento da participação dos usuários do Facebook nesses eventos online. Os internautas começaram a confirmar sua presença nos eventos dos protestos de junho.

Quando um usuário do Facebook ou um usuário que possui uma fanpage abre um evento, ele pode convidar seus amigos e/ou seguidores para o evento, e seus amigos podem convidar outros amigos, e assim sucessivamente. Outra ação que pode ocorrer consiste no compartilhamento do evento na timeline de pessoas, o que gera mais visibilidade ainda.

Uma dificuldade encontrada foi achar os eventos no Facebook e também o fato de que durante os atos não eram criados novos eventos e sim atualizados por cima do outro, mudando data, horário e local, então se perderam alguns eventos no Facebook. Colocaremos os que não foram atualizados para que não haja perda maior de fidelidade aos números reais de pessoas que confirmaram ou foram convidadas para os atos de junho em Brasília.

Tabela 3 - eventos no Facebook das manifestações em Brasília, no mês de junho de 2013 (continua na próxima página)

\begin{tabular}{|c|c|c|c|c|c|c|}
\hline Evento & Dia / Mês & $\begin{array}{c}\text { Pessoas } \\
\text { convidadas }\end{array}$ & Talvez & $\begin{array}{c}\text { Pessoas } \\
\text { confirmadas }\end{array}$ & Pauta(s) do Ato & Organizadores \\
\hline $\begin{array}{l}\text { Protesto Pacífico na } \\
\text { Copa das Confederaçōes }\end{array}$ & $15 / 06$ & 18.500 & 648 & 646 & $\begin{array}{l}\text { Contra a corrupção, fome, má educação, } \\
\text { saúde precária, segurança, justiça e contra } \\
\text { tudo que nosso Brasil tem de ruim. }\end{array}$ & Ativista Independente \\
\hline $\begin{array}{l}\text { Marcha do Vinagre na } \\
\text { Festa de } 5 \text { milhões }\end{array}$ & $15 / 06$ & 4.500 & 74 & 324 & $\begin{array}{l}\text { Contra a violência e a impunidade, por saúde, } \\
\text { segurança, cidadania e respeito. }\end{array}$ & Ativistas Independentes \\
\hline $\begin{array}{l}\text { Apoio aos manifestantes de SP } \\
\text { e todo país + Copa pra quem? }\end{array}$ & $17 / 06$ & 63.200 & 2.000 & 8.200 & Pauta indefinida & Ativistas Independentes \\
\hline $\begin{array}{l}\text { Manifestação: } \\
\text { TARIFA ZERO VAI } \\
\text { VIRAR REALIDADE }\end{array}$ & 19/06 & 91.800 & 2.600 & 9.300 & Tarifa zero; e Transporte 24 horas. & MPL-DF \\
\hline $\begin{array}{l}\text { Ato Nacional contra } 0 \\
\text { aumento das passagens }\end{array}$ & $20 / 06$ & 94.500 & 3.000 & 13.400 & Contra 0 aumento das passagens & $\begin{array}{l}\text { Juntos Brasília; Comitê Brasil } \\
\text {; e atores políticos de outras } \\
\text { organizações }\end{array}$ \\
\hline $\begin{array}{l}\text { Bloco Não à cura LGBTTT no dia do } \\
\text { ato Nacional no DF! }\end{array}$ & $20 / 06$ & 4.800 & 57 & 296 & $\begin{array}{c}\text { Apoio à pauta do Ato Nacional contra } 0 \\
\text { aumento das passagens; e Renúncia do } \\
\text { Deputado Feliciano. }\end{array}$ & Anel Brasília \\
\hline Marcha das Vadias & $22 / 06$ & 41.200 & 1.300 & 6.000 & $\begin{array}{l}\text { Pelo fim das violências } \\
\text { contra as mulheres. }\end{array}$ & Marcha das Vadias \\
\hline $\begin{array}{l}\text { Marcha do Vinagre!Vamos parar } \\
\text { Brasília! }\end{array}$ & $22 / 06$ & 276.000 & 9.500 & 30.800 & Não especificada & Ativistas Independentes \\
\hline
\end{tabular}

8 O link para cada evento estudado se encontra nas referências bibliográficas no fim deste artigo. 
Tabela 3 - eventos no Facebook das manifestações em Brasília, no mês de junho de 2013 (continuação da página anterior)

\begin{tabular}{|c|c|c|c|c|c|c|}
\hline Evento & Dia / Mês & $\begin{array}{l}\text { Pessoas } \\
\text { convidadas }\end{array}$ & Talvez & Pessoas confirmadas & Pauta(s) do Ato & Organizadores \\
\hline $\begin{array}{l}\text { Movimento contra a pec } 37 \\
\text { Brasília }\end{array}$ & $26 / 06$ & 54.100 & 1.900 & 7.100 & Contra a pec 37. & Ativistas Independentes \\
\hline Protesto contra a PEC 37 & $26 / 06$ & 101.600 & 3.400 & 12.700 & Contra a pec 37. & Ativistas Independentes \\
\hline $\begin{array}{l}\text { \#Forafeliciano - quem } \\
\text { derrubou o preço das tarifas, } \\
\text { vai derrubar Feliciano! }\end{array}$ & $26 / 06$ & 43.800 & 1.000 & 5.100 & $\begin{array}{c}\text { Derrotar a "cura gay" e derrubar } \\
\text { Feliciano. }\end{array}$ & $\begin{array}{c}\text { Juntos, Pedra no sapato, } \\
\text { Movimento Honestinas, } \\
\text { Domínio Público, ANEL, } \\
\text { Rompendo Amarras }\end{array}$ \\
\hline II Protesto em Taguatinga & $28 / 06$ & 9.000 & 323 & 766 & Não especificada & $\begin{array}{c}\text { Comitê Popular da Copa } \\
- \text { DF }\end{array}$ \\
\hline $\begin{array}{l}\text { Globo, você NÃ̃ nos } \\
\text { representa! }\end{array}$ & $28 / 06$ & 8.200 & 121 & 695 & $\begin{array}{l}\text { Ato unificado com o "Ato contra a PM } \\
\text { truculenta do governo Agnelo"; } \\
\text { questionar a grande mídia sobre as } \\
\text { mentiras que são lavradas pelo país. }\end{array}$ & Ativistas Independentes \\
\hline $\begin{array}{l}\text { Ato contra a PM truculenta do } \\
\text { governo Agnelo }\end{array}$ & $28 / 06$ & 18.000 & 303 & 993 & $\begin{array}{l}\text { Ato unificado com o evento “Globo, } \\
\text { você NÃ0 nos representa!"; e contra a } \\
\text { truculência policial do DF }\end{array}$ & $\begin{array}{l}\text { Juntos Brasília ; Anel } \\
\text { Brasília; e Ativistas } \\
\text { Independentes }\end{array}$ \\
\hline Revolução do Vinagre & $29 / 06$ & 13.800 & 375 & 1.300 & Não especificada & Ativistas Independentes \\
\hline $\begin{array}{l}\text { Copa pra Quem? - Contra } \\
\text { as violações da Copa } \\
\text { e pela restituiçãa dos } \\
\text { R\$2.800.000,00 dos ingressos } \\
\text { de Agnelo!!! }\end{array}$ & $30 / 06$ & 5.300 & 89 & 286 & $\begin{array}{l}\text { Contra as violaçōes da Copa e pela } \\
\text { restituição dos R } \$ 2.800 .000,00 \text { dos } \\
\text { ingressos de Agnelo!!! }\end{array}$ & $\begin{array}{c}\text { Comitê Popular da Copa } \\
- \text { DF }\end{array}$ \\
\hline $\begin{array}{c}\text { Marcha das Crianças - Por um } \\
\text { Brasil Melhor }\end{array}$ & $30 / 06$ & 37.600 & 1.400 & 4.700 & $\begin{array}{l}\text { Por um Brasil melhor hoje, por um Brasil } \\
\text { melhor no futuro, a intenção é marchar } \\
\text { com segurança e paz e batalhar para que } \\
\text { as crianças cresçam e tenham orgulho } \\
\text { do país em que vivem. }\end{array}$ & Ativistas Independentes \\
\hline
\end{tabular}


$\mathrm{Na}$ abertura da Copa das Confederações e no jogo Brasil versus Japão, aconteceu o primeiro ato que acabou desencadeando em outras manifestações. O protesto foi organizado pelo Comitê Popular da Copa, porém não houve evento no Facebook criado pelo Comitê. De acordo com entrevista feita a Silva (2014, grifo nosso), membro do Comitê Popular da Copa - DF, houve queima de pneus, ${ }^{9}$ que impedia o acesso à pista que dava ao estádio Mané Garrincha, onde aconteceu a inauguração da Copa. Já os ativistas independentes criaram dois eventos no $\mathrm{Fa}$ cebook, o primeiro do dia 15/06 da tabela acima, em que teve maior incidência de confirmações 646; e o segundo evento da tabela, que também estava marcado para o dia 15/06, com 324 pessoas confirmadas. Ambos os eventos com pautas mais abrangentes.

Sentimentos como solidariedade estavam presentes entre as pautas dos eventos como os do dia $17 \mathrm{de} \mathrm{ju-}$ nho, que foram organizados em solidariedade aos manifestantes de São Paulo e de todo país. Este acabou sendo nas ruas um dos grandes atos em Brasília, quando ocorreu a ocupação da rampa do Congresso Nacional.

Destaca-se dos demais eventos a Marcha do Vinagre, que ocorreu dia 22, tendo audiência de 30.800 pessoas confirmadas, os organizadores foram ativistas independentes e dos eventos analisados neste estudo obtiveram o maior número de confirmações em evento no Facebook.

No dia 26 de junho, também ocorria o Ocupa que não foi possível analisar, pois o link para o evento em Brasília não estava mais disponível e só era possível visualizar o evento nacional que disponibiliza os links paras as várias cidades no Brasil e mundo.

Em entrevistas realizadas com Silva (2014) e Gomes (2014), ${ }^{10}$ do Comitê Popular da Copa, perguntamos como eles explicavam a organização de eventos por ativistas independentes que não haviam participado de movimentos sociais. A auto-organização foi ressaltada e usada para explicar como os vários eventos online, alguns até no mesmo dia e mesmo lugar, foram criados. Segundo Silva (2014, grifo nosso): Você tem uma dinâmica que se institui ali no momento, na rede, que foge do controle das organizações tradicionais. E essas organizações têm

9 Disponível em: <http://www1.folha.uol.com.br/esporte/ folhanacopa/2013/06/1295681-manifestacoes-se-espalham-pelas-sedes-do-torneio.shtml>. Acesso em: 16 jun. 2014.

10 Entrevista concedida a Fernanda A. F. Fidelis. Brasília, 2014. 1 arquivo. mp3 (35 min). dificuldade com isso, pois querem usar suas técnicas, suas práticas em uma dinâmica que é totalmente diferente, num contexto diferente (Informação verbal).

\section{Resultados e discussão}

Não conseguimos contatar os ativistas independentes que foram os organizadores dos eventos que tiveram alto número de confirmações. Na época do estudo, fizemos contato com membros do Comitê Popular da Copa e MPL do Distrito Federal. Por meio dessas entrevistas, chegamos ao conhecimento dos ativistas independentes e de sua interação com esses grupos. Assim tentamos entrar em contato com os ativistas independentes, porém não foi possível. Foram criados nomes fictícios para os entrevistados, com a finalidade de preservar o anonimato.

A priori havia sido definido que seriam estudadas 15 postagens do Comitê Popular da Copa e do MPL, porém em junho de 2013 só havia 12 postagens do MPL. Por isso, no tópico referente à pesquisa do MPL só serão encontradas 12 postagens. E do Comitê Popular da Copa - DF, estudamos as 15 postagens.

No que diz respeito às postagens no Facebook das fanpages do MPL-DF e do Comitê Popular da Copa - DF, foi possível observar um padrão de publicações. As categorias dividiram-se em quatro: a primeira é de mobilização, que concerne aos assuntos de divulgação de eventos na rua ou virtuais; a segunda, debate político, que tem caráter informacional, a fim de trazer esclarecimentos sobre as pautas abordadas na fanpage; de denúncia; e, por último, a de apoio a outra organização que engloba solidariedade e/ou divulgação de outros grupos políticos.

As categorias que foram colocadas para classificar as postagens dos dois grupos podem se enquadradas nas três explicações que Valenzuela (2013) dá para relação entre a frequência do uso de mídia social e participação política que são: informação; expressar opinião; e ativismo Valenzuela (2013, p. 921).

As categorias criadas para classificar o teor dos assuntos das fanpages estudadas tinham cunho informacional, e em alguns momentos expressivas também a opinião dos coletivos, como, por exemplo, a postagem do dia $13 \mathrm{de} \mathrm{ju-}$ nho do MPL-DF, em que se pronunciaram para falar sobre as manifestações de 10 anos atrás e dando parecer sobre o ciclo de protestos que na opinião do grupo se iniciaria. 
No presente estudo, as quatro categorias talvez possam ser específicas para o mês de junho de 2013, por ser um momento de efervescência política no Brasil. Para saber se só essas categorias seriam suficientes para entender como se dá as postagens nas fanpages seria necessário estudar as mesmas fanpages analisadas neste estudo em outro momento.

Neste estudo, mostramos que o posicionamento, quanto à utilização do Facebook, do MPL-DF e do Comitê Popular da Copa, foi um pouco diferente se comparado um ao outro. O MPL-DF deixou claro que o Facebook consiste em uma ferramenta para alcançar um público que eles não atingiriam com seu trabalho de base nas ruas. Enquanto o Comitê Popular acredita que o Facebook era uma excelente ferramenta para expressar opiniões e poder ter voz, alcançando vários públicos.

No período de junho de 2013, o MPL-DF organizou um evento no Facebook, que teve o total de 91.800 pessoas convidadas e 9.300 confirmadas (um pouco mais que $10 \%$ do total de pessoas convidadas). Esse evento apareceu na fanpage do MPL e recebeu quatro curtidas. Outro evento divulgado na página do MPL-DF foi o "II Protesto em Taguatinga", organizado pelo Comitê Popular da Copa, que ocorreu no dia 28 de junho de 2013, essa postagem recebeu 12 curtidas. Essas duas postagens foram referentes à mobilização online no intuito de convocar as pessoas a irem às ruas.

A fanpage do Comitê Popular da Copa - DF organizou dois eventos no mês de junho de 2013. E, as postagens com mais compartilhamento e curtidas foram referentes ao debate político, que eram referentes à campanha do cartão vermelho para a Copa. Pelas postagens a preocupação maior do Comitê era o debate político; seguida de denúncias e mobilização.

A despeito de não termos conseguido entrevista com os ativistas independentes, constatamos com base nos gráficos que os eventos organizados por militantes autônomos tiveram um maior número de pessoas confirmadas em relação a movimentos sociais organizados, atuando isoladamente no Facebook, como aponta o ranking de frequência abaixo:

1. a Marcha do Vinagre ocorrida no dia 22 de junho foi o evento que teve o maior número de confirmações, aproximadamente 30.800,
2. seguido do ato nacional contra o aumento das passagens no dia 20 de junho, que teve 13.400 confirmações e foi organizado por vários movimentos sociais unificados.

3. em terceiro lugar, com 12.700 confirmações, o evento do protesto contra a PEC 37 organizado por ativistas independentes que aconteceu no dia 26 de junho.

4. o evento do MPL-DF alcançou 9.300 confirmações e ocorreu no dia 19 de junho.

Os dados acima refletem que os ativistas independentes foram responsáveis por uma maior mobilização no espaço online.

Gráfico 1 - evolução da Audiência dos Eventos no Facebook dos Protestos de junho de 2013 no DF

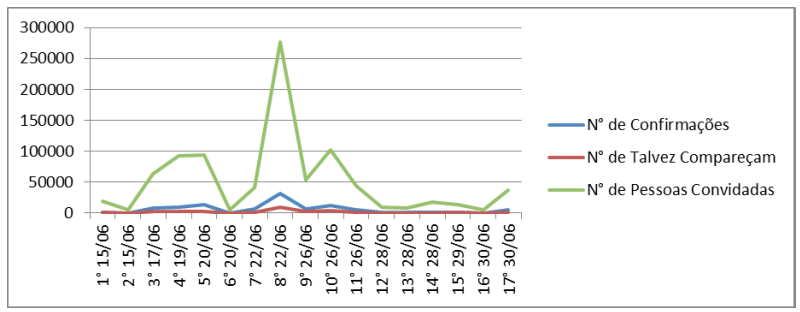

Fonte: Facebook

Os gráficos revelam que os eventos com mais pessoas convidadas para os protestos apresentavam um maior número de confirmações. Nos primeiros eventos, poucas pessoas foram convidadas e ocorreu um aumento no número de convidados do dia 15/06 para o dia 19/06, foi um espaço curto de tempo. No dia 20/06, que foi o Ato Nacional contra o aumento das passagens, organizado por vários grupos, teve um número baixo de pessoas convidadas. Já no dia 22/06, temos o índice mais alto de número de pessoas convidadas e confirmadas. Depois o gráfico apresenta queda em nos três tipos de resposta (convidadas, talvez, confirmadas) para os eventos. Foi possível ver nos eventos organizados no Facebook que havia várias pautas e alguns eventos acabaram sendo programados para o mesmo dia. Isto mostra a questão da autogestão, em que os manifestantes, por não terem de forma clara quem era dirigentes e dirigidos, a pauta era mais solta a critério dos ativistas independentes. Já o caso de poucos de alguns eventos que eram feitos por movimentos sociais os eventos tinham pauta formada, mas não obtiveram o mesmo sucesso em números de acesso no Facebook. Sobre a questão de autogestão e pautas Chauí (2014), diz o seguinte sobre as manifestações de 2013: 
O fato de os manifestantes confundirem o que significa ter uma direção e o que significa ter uma liderança. Como eles se organizam em termos de autogestão e horizontalidade, sem dirigentes e dirigidos, eles identificam ter um rumo com ter um líder. Não percebem que não é a mesma coisa. As manifestações, por enquanto, estão sem rumo; têm palavras de ordem as mais variadas, mas não um rumo, o que as torna frágeis e apropriáveis pela mídia e pela direita (CHAUI, 2014, p. 45).

Uma preocupação do Comitê Popular da Copa, como Gomes (2014, grifo nosso), falou em entrevista, foi de trazer para perto deles um ativista que foi responsável por criar alguns dos eventos no Facebook que tiveram maior número de acessos. Esse ativista foi chamado para participar do Comitê e assim eles puderam digamos dar certa orientação política.

Os últimos protestos de junho de 2013 em Brasília começaram a diminuir sua audiência na rua e os acessos no Facebook, talvez como Chauí (2014, p. 45) falou sobre a falta de rumo às manifestações, acabaram perdendo pessoas pelo caminho, no caso de Brasília, pelo que acompanhamos nos eventos deste estudo.

\section{Considerações finais}

Um fato que pode ajudar a explicar o uso do $\mathrm{Fa}$ cebook como ferramenta para mobilização online é a relativamente densa capilaridade que as redes sociais adquiriram nos últimos anos na região. Entre 2007 e 2011, o Facebook apresentou taxa de crescimento de sua audiência na América Latina de 6,4\% para 84,1\%. Essa rede social digital atingiu $12 \%$ da audiência da Internet em dezembro de 2007, ao passo que, em dezembro de 2011 alcançou 55\%. A América Latina foi a região que apresentou maior penetração nesse período ${ }^{11}$. De acordo com a pesquisa do IBOPE (2014), o uso do Facebook foi maioria absoluta como forma de informação e divulgação dos protestos de junho de 2013. A criação de eventos no Facebook e a participação tão intensa dos usuários dessa mídia social pode indicar uma nova forma de mobilizações para protestos no Brasil e que segue uma tendência mundial. Vimos no Egito, de acordo com Castells (2013),

11 De acordo com os dados do site ComScore (2013). Facebook shows strong growth over past Five years. Disponível em: <http://www.comscoredatamine.com/2012/02/facebook-shows-strong-growth-over-past-five-years/>. Acesso em: 27 maio 2014. que o uso do Twitter foi essencial na Primavera Árabe e, no Brasil, a mídia social mais usada foi o Facebook.

Conseguimos responder às perguntas propostas no início deste estudo, porém não foi possível fazer a análise que pretendíamos em virtude da quantidade de achados que tivemos ao longo dessa empreitada. Para futuros trabalhos, temos a pretensão de dar continuidade a uma análise mais profunda dos dados.

Como apontam os dados dos eventos no Facebook, junho foi um mês de dezenas de atos populares em Brasília cuja iniciativa da participação dos manifestantes teve considerável influência do ambiente online. $\mathrm{O}$ advento das novas tecnologias da informação colocou na ordem do dia uma série de debates conjunturais importantes para o conjunto dos cidadãos. Assim, pode-se inferir que houve afloramento do sentimento de consciência política e responsabilidade social no que tange direitos e deveres sociais.

As novas formas de organização e associação dos ativistas independentes e movimentos sociais fogem do controle dos movimentos e ativismos tradicionais, as formas clássicas de manifestações mudaram. Outro importante fator a ser destacado consiste na auto-organização de manifestações que se dão de forma independente e horizontal. De acordo com Silva (2014, grifo nosso):

Os fenômenos de multidão vêm tomando o mundo numa forma de organização alternativa, diferente da que a gente está acostumado, não são organizações políticas que se reúnem. Se tem uma dinâmica instituída ali no momento, na rede, que foge do controle das organizações formais (Informação verbal).

$\mathrm{O}$ que nos chamou a atenção neste estudo foi a ruptura com o modelo de manifestações isoladas a que estávamos acostumados há alguns anos. Em novembro de 2012, por exemplo, aconteceu uma manifestação contra o genocídio do povo indígena Guarani Kaiowá ${ }^{12}$ na Esplanada dos Ministérios. Antes de junho poucas manifestações dialogavam com a quantidade de pautas que a jornada de junho dialogou. Um exemplo disso é, como apontado no gráfico acima, num mesmo dia, eventos diferentes, com

12 Manifestação organizada pelo Centro Acadêmico de Sociologia da UnB. A intervenção lúdica foi realizada na aula magna que é organizada pela reitoria da UnB. Esta visava convocar os estudantes para um ato na esplanada dos ministérios, em Brasília, na semana seguinte. Disponível em $<$ http://www.youtube.com/watch?v=dzn65DyClSU $>$. Acesso em: 01 jul. 2014. 
pautas diferentes dialogavam entre si nas ruas de Brasília. Manifestações contra a PEC 37, Fora Feliciano, Ato contra a Repressão policial, Ato contra a Rede Globo, são alguns dos exemplos.

$\mathrm{O}$ ativismo online no Facebook conforme averiguamos neste estudo parece ter influenciado a população, e se pode observar que essa mídia social foi fundamental nas manifestações de junho de 2013. De acordo com os apontamentos da pesquisa do IBOPE (2014), que indicou que a maioria absoluta das pessoas entrevistadas utilizou o Facebook para se informar sobre as manifestações. Uma nova forma de transmitir informação e de se debater política, já que a maneira de se organizar uma mobilização de rua ocorre no meio virtual e os movimentos sociais têm a possibilidade de usar essas ferramentas para dialogar com vários grupos de pessoas.

Outro fator importante de ser analisado consiste na relação da pauta material com o conjunto das manifestações em Brasília. $\mathrm{O}$ fato de não haver aumento de tarifas no DF há mais de oito anos ${ }^{13}$ dialoga com a dificuldade de mobilização popular que o MPL-DF teve para aglutinar em torno do debate do transporte público brasiliense. Diferentemente de outras capitais, como Goiânia, Porto Alegre, São Paulo, onde se teve aumento de tarifas.

\section{Referências}

BIMBER, Bruce; FLANAGIN, Andrew; Cynthia Stohl. Collective action in organizations: interaction and engagement in an era of technological change. Cambridge: Cambridge University Press, 2012.

CASTELLS, M. A galáxia da Internet: reflexões sobre a Internet, os negócios e a sociedade. Rio de Janeiro: Zahar, 2003.

CASTELLS, M. A Sociedade em rede: a era da informação: economia, cultura. São Paulo: Paz e Terra, 1999. v. 1.

CASTELLS, M. La wikirrevolución del jazmín. La Vanguardia. Disponível em: <http://www.lavanguardia.com/ opinion/articulos/20110129/54107291983/la-wikirrevolucion-del-jazmin.html>. Acesso em: 24 maio 2014.

13 O último aumento de passagens se deu em janeiro de 2006, como aponta o jornal correio braziliense. Disponível em: $<$ http://www.correiobraziliense.com.br/app/noticia/cidades/2010/11/16/interna_cidadesdf,223244/empresas-de-onibus-cobram-aumento-na-passagem-e-fazem-ameacas. shtml>. Acesso em: 01 jul. 2014.
CASTELLS, M. Redes de indignação e esperança: movimentos sociais na era da internet. Rio de Janeiro: Zahar, 2013.

COMSCORE. Facebook shows strong growth over past Five years. 2003. Disponível em: <http://www.comscoredatamine.com/2012/02/facebook-shows-strong-growth-over-past-five-years/>. Acesso em: 27 maio 2014.

CHAUI, Marilena. Pela responsabilidade intelectual e política. Revista Cult, São Paulo, n. 1, p. 43-52, janeiro 2014.

EARL, Jennifer et al. Changing the world one webpage at a time: conceptualizing and explaining internet activism, $\mathrm{Mo}$ bilization, San Diego, v. 15, n. 4, p. 425-446, dezembro 2010.

GOHN, Maria da Glória. Movimentos sociais e redes de mobilizações civis no Brasil contemporâneo. Petrópolis: Vozes, 2010.

GOHN, Maria da Glória. Movimentos sociais na contemporaneidade. Revista Brasileira de Educação, v. 16, n. 47, p. 333-361, 2011. Disponível em: <http://www.scielo.br/pdf/ rbedu/v16n47/v16n47a05.pdf>. Acesso em: 22 maio 2014.

GOHN, Maria da Glória. Teoria dos movimentos sociais: paradigmas clássicos e contemporâneos. 5. ed. São Paulo: Loyola, 2006.

IBOPE, 2013. Pesquisa de opinião pública sobre as manifestações. Disponível em: <http://www.ibope.com.br/pt-br/ noticias/Documents/JOB_0948_BRASIL\%20-\%20Relatorio\%20de\%20tabelas.pdf>. Acesso em: 16 nov. 2014.

MARCHA do Vinagre. Disponível em: <https://www.facebook.com/events/645805775444538/?ref=23>. Acesso em: 24 jun. 2014.

MARICATO, Ermínia et al. Cidades rebeldes: passe livre e as manifestações que tomaram as ruas do Brasil. São Paulo: Boitempo; Carta Maior, 2013.

MOVIMENTO contra a pec 37 Brasília. Disponível em: <https://www.facebook.com/events/128216877384906/?ref=23 >. Acesso em: 24 jun. 2014.

MOVIMENTO Passe Livre- Distrito Federal. Perfil do MPL-DF no Facebook. Disponível em: <https://www.facebook.com $/ \mathrm{mpldf}$ ?ref=ts\&fref=ts\#!/mpldf/info $>$. Acesso em: 2 jun. 2014.

MOVIMENTO dos Sem Terra. Perfil do MST no Facebook. Disponível em: <https://www.facebook.com/\#!/ MovimentoSemTerra?fref=ts $>$. Acesso em: 1 maio 2015.

MOVIMENTO dos Trabalhadores Sem Teto. Perfil do MTST no Facebook. Disponível em: <https://www.facebook.com/\#!/mtstbrasil?fref=ts $>$. Acesso em: 1 maio 2015. 
OLSON, Mancur. A lógica da ação coletiva: os benefícios públicos e uma teoria dos grupos sociais. São Paulo: Universidade de São Paulo, 2011.

PATRÍCIO, Djalma. Poder, grupos de pressão e meios de comunicação. Blumenau: FURB, 1998.

ROVIRA, J. Castells sobre internet e rebelião: "É só o começo." [Entrevista] Trad. Cauê Seigne Ameni. Outras Palavras. [Revista Eletrônica]. Disponível em: $<$ http://www. outraspalavras.net/2011/03/01/castells-sobre-internet-e-insurreicao-e-so-o-comeco/>. Acesso em: 24 maio 2014.

SINGER, André. Brasil, junho de 2013: classes e ideologias cruzadas. Novos estud. - CEBRAP [online]. 2013, n. 97, p. 23-40. Disponível em:<http://www.scielo.br/scielo. php?pid=S0101-33002013000300003\&script=sci_arttext\&tlng=es $>$. Acesso em: 25 maio 2014.

SOCIAL Bakers. Detailed statistics on MidiaNinja's Facebook page. Disponível em: <http://www.socialbakers. com/facebook-pages/164188247072662-ninja>. Acesso em: 27 maio 2014.

SCHERER-WAREN, Ilse. Das mobilizações às redes de movimentos sociais. Sociedade e Estado, Brasília, v. 21, n. 1, p. 109-130, jan./abr. 2006. Disponível em: <www.scielo. br/pdf/se/v21n1/v21n1a07.pdf>. Acesso em: 6 mar. 2015.

SOCIAL Bakers. Detailed Statistics on MPL-DF's Facebook Page. Disponível em: <http://www.socialbakers. com/facebook-pages/259970814044699-mpl-df >. Acesso em: 19 jun. 2014.
SOUSA, Cidoval Morais de. et al. Jornadas de junho: repercussões e leituras. Campina Grande: EDUEPB, 2013. Disponível em: <https://www.google.com.br/ url $? \mathrm{sa}=\mathrm{t} \& \mathrm{rct}=\mathrm{j} \& \mathrm{q}=\& \mathrm{esrc}=\mathrm{s} \&$ source $=\mathrm{web} \& \mathrm{~cd}=1 \& \mathrm{ca}-$ $\mathrm{d}=$ rja\&uact $=8 \&$ ved $=0 \mathrm{CB} 4 \mathrm{QFjAA} \&$ url $=\mathrm{http} \% 3 \mathrm{~A} \%$ 2F\%2Fwww.uepb.edu.br\%2Fdownload\%2Febooks\%2FJornadas\%2520de\%2520Junho\%2520-\%2520Repercuss \%25C3\%25B5es\%2520e\%2520Leituras.pdf\&ei=MsexU_nwCueysQSdxYDIDA\&usg=AFQjCNErciJpZlOOpIHw1 nvEUu9fVifh-g\&bvm=bv.69837884,d.cWc $>$. Acesso em: 30 jun. 2014.

TELLES, André. A revolução das mídias sociais: cases, conceitos, dicas e ferramentas. São Paulo: M. Books do Brasil, 2010.

TOURAINE, Alain. O que é democracia? Petropólis: Vozes, 1996.

TORO, José Bernardo; WERNECK, Nisia Maria Duarte Furquim. Mobilização social: um modo de construir a democracia e a participação. UNICEF - Brasil, 1996.

VALENZUELA, Sebastián. Unpacking the use of social media for protest behavior: the roles of information, opinion expression and activism. American Behavioral Scientist, v. 57, n. 7, p. 920-942, março 2013. 